\title{
いわゆる健康食品の衛生学的調査 (I)
}

(昭和 59 年 2 月 13 日受理)

\begin{tabular}{|c|c|c|}
\hline 安田和 男* & 西島基 弘* & 斉藤和夫* \\
\hline 上村 尚* & 井部 明 広* & 永山敏 廣* \\
\hline 牛山博文* & 田 端 節 子* & 松本幸子* \\
\hline 直井家壽太* & 二島太一郎* & \\
\hline
\end{tabular}

\section{Hygienic Studies on "Health Food" (1) Chemical and Biological Survey}

\section{Kazuo Yasuda, Motohiro Nishijima, Kazuo Saito, Hisashi Kamimura, Akihiro Ibe, Toshihiro Nagayama, Hirofumi UshiYama, Setsuko TABATA, Sachiko Matsumoto, Yasuta NaOI and Taichiro Nishima}

(Tokyo Metropolitan Research Laboratory of Public

Health: 24-1, Hyakunincho 3-chome, Shinjuku-ku, Tokyo, Japan)

Key words: 健康食品 health food; 変異原性（サルモネラ TA 98) mutagenicity (Salmonella typhimurium TA 98); 鷄肧致死試験 chicken embryo assay; 残留農薬 pesticide residue; 微量元素 trace element; アフラトキシン aflatoxin; ケルセチン quercetin; 高麗人参 Korean ginseng; 花粉 pollen; 胚芽 embryo bud

\section{緒言}

近年，いわゆる健康食品として多種多様の製品が市販 されるようになってきた。ここらの原料は一般に食品と 言われるものの概念とは異なったものが多く, 消費者は 単なる食品としてではなく，健康に対して何らかの効果 を期待してこれらを摂取する場合が多い，しかし，これ らは医薬品ではなく食品であるといら観点から摂取方法 の詳細な説明がないもの, あるいは不明確なるのなども あり, 人によっては常識外飞多量に, かつ, 連用する可 能性もある。

さらに, 最近, 品質などに関しての苦情, あるいは品 質の劣化が原因と思われる中毒1).22 も発生し，その安全 性が問題とされている.

そこで, 昭和58年 9 月, 厚生省はいわゆる健康食品に 対し, 含有成分, 製造方法, 表示などの実態を調查する と共に，成分分析，危害度評価などを行い，昭和60年を 目標に規格基準を定めて法的規制を検討する方針を発表 した.

* 東京都立衛生研究所：東京都新宿区百人町 3-24-1
これまでに，いわゆる健康食品に対し衛生学的検討が ほとんど行われていないので，著者らは，市販されてい るいわゆる健康食品に対し昭和54年から, 種々の衛生学 的調查を行っている. 本報ではそれらに対し, 有害元素 を中心とする各種元素, 農薬, カビ毒, ホルムアルデヒ ド及び食品添加物などの調查を実施し，一部のものに対 しては変異原性試験及び舀胚致死試験の生物学的試験を も，あわせて行ったのでその結果を報告する.

\section{実験の部}

1. 試料

試料は都内デパートの健康食品あるいは自然食品コー ナー, または薬局, 健康食品専門店などで市販されてい たもので形態が液状, 粉末, 顆粒及び錠剂様の製品を選 んだ.

液状製品は野菜, 果実などの植物エキス飲料 23 検体, 酵素飲料15検体, カルシウムなどの元素含有飲料 6 検体 及び海産物エキス濃縮液 3 検体の計 47 検体, 粉末, 顆粒 及び錠剂様製品は主原料が野菜，果実などの植物性のも の40検体, 酵素のもの 7 検体, 海産物のもの 7 検体及び 卵壳, 骨粉などのもの 5 検体の計59検体を調査した。 


\section{2. 標準溶液及び試薬}

1) 各元素標準溶液: $\mathrm{Hg}, \mathrm{As}, \mathrm{Pb}, \mathrm{Cd}, \mathrm{Cr}, \mathrm{Sb}, \mathrm{Sn}$, $\mathrm{Cu}, \mathrm{Zn}, \mathrm{Mn}, \mathrm{Co}, \mathrm{Fe}, \mathrm{Mg}$ 及び $\mathrm{Ca}$ は原子吸光用標準液 $(1,000 \mathrm{ppm}$, 和光純薬製) を用時, 適宜, $1 N$ 硝酸ある いは $1 N$ 塩酸で一定量に希釈して用いた.

2) アフラトキシン $\mathrm{B}_{1}, \mathrm{~B}_{2}, \mathrm{G}_{1}$ 及び $\mathrm{G}_{2}$ 混合標準溶 液：いずれも Makor Chemicals 社製品をベンゼンーア セトニトリル (98:2) 混液に溶解してそれぞれアフラト キシン $\mathrm{B}_{1} 2.0 \mathrm{ppm}, \mathrm{B}_{2} 1.0 \mathrm{ppm}, \mathrm{G}_{1} 3.0 \mathrm{ppm}$ 及び $\mathrm{G}_{2}$ $1.0 \mathrm{ppm}$ になるよらに調製した.

3）薄層クロマトグラフィー用プレート：DC-Fertigplatten Kieselgel 60 (Merck 社製)

4) カラムクロマトグラフィー用シリカゲル：Kieselgel 60 (Merck 社製)

5） その他の試薬：元素の分析はすべて精密分析用, 農薬の分析は残留農薬用, その他の項目はいずれも市販 特級品を用いた。

3. 装

1）原子吸光光度計：日本ジャーレルアッシュ社製 AA-780 型

2) ポーラログラフ：柳本製作所製 P8 型

3） ガスクロマトグラフ：島津製作所製 GC-5A 型

4) デンシトメーター：日立製作所製 MPF-2A 型

5) 自記分光光度計：日立製作所製 EPS-3T 型

6）高速液体クロマトグラフ：日立製作所製 633 型

4. 分析方法

1）有害性元素及びその他の元素：日本薬学会編, 衛 生試験法・注解に従い, 試料を湿式灰化したのち, Sn はポーラログラフィー, Pb, Cd, Cr, Sb, Cu, Zn, Mn, $\mathrm{Co}, \mathrm{Fe}, \mathrm{Mg}, \mathrm{Ca}$ 及び $\mathrm{As}$ はフレーム原子吸光法, 総水 銀は還元気化フレームレス原子吸光法, B (ホウ酸とし て）は比色法により測定を行った.

2) 農薬：厚生省告示第 332 号及び 333 号に準じて 分析を行い, 有機塩素剤は ECD-GC, 有機リン剂は FPD-GC により測定を行った.

カラム充てん成 i) 5\% DEGS-1\% リン酸 (Chromosorb W) ii) 2\% OV-17 (Gaschrom Q) iii) $10 \% \mathrm{QF}-1$ (Gaschrom Q)

3) カビ毒: アフラトキシン $\mathrm{B}_{1}, \mathrm{~B}_{2}, \mathrm{G}_{1}$ 及び $\mathrm{G}_{2}$ につ いて厚生省通知による方法 ${ }^{3)}$ に準じて分析した. すなわ ち, 試料をメタノール $-1 \%$ 食塩水 $(55: 45)$ 混液で抽出 し, へキサンで脱脂後, クロロホルムに転溶した. クロ ロホルム層を濃縮し, シリカゲルカラムクロマトグラフ ィーによりクリーンアップ後, 薄層クロマトグラフィー を行い, 蛍光デンシトメトリーにより定量した。

測定条件 Ex. $368 \mathrm{~nm} \mathrm{Em.} 444 \mathrm{~nm}$

4) ホルムアルデヒド及び食品添加物：日本薬学会 編, 衛生試験法・注解に従った。

5） 3,4-ベンツピレン：衛生試験法・注解に準じ, ア
ルカリでけん化し, へキサン抽出後, シリカゲルカラム クロマトグラフィーを行い, クリーンアップ後, 高速液 体クロマトグラフィーを行った。

測定条件 カラム ODS $(4 \phi \times 250 \mathrm{~mm})$

移動相 アセトニトリルー水 $(70: 30)$

Ex. $384 \mathrm{~nm}$ Em. $406 \mathrm{~nm}$

6) ケルセチン: 試料をメタノノルで抽出し, 濃縮後, ペーパークロマトグラフィー用口紙に塗布し，30\% 酢 酸で展開後, 紫外線 $(365 \mathrm{~nm})$ 照射下でケルセチン標準 物質と同じ $\mathrm{R} f$ 值に同様の蛍光を呈する部分を切り取 り,メタノールで溶出した。メタノール溶液を濃縮乾固 後, 残留物をアセトンに溶解し, シリカゲル薄層プレー トに塗布し,トルェンーギ酸ーギ酸エチル $(5: 1: 4)$ で展開 後, 紫外線照射下で試料及び標準物質のスポットと $\mathrm{R} f$ 值及び蛍光色調を比較してケルセチンの有無を確認し た。

次に, $4 \%$ 硫酸アルミニウム溶液を薄層プレートに噴 霧し増蛍光した後, 蛍光デンシトメーターにより蛍光ス ペクトル $(\mathrm{Ex} .380 \mathrm{~nm})$ 及び励起スペクトル (Em. 500 $\mathrm{nm}$ ) を測定し, 標準物質のスペクトルと比較して判定 した.

7）変異原性試験：試料が透明な液状の場合はそのま ま，その他の試料は水を加えて一定量とした後，0.45 $\mu \mathrm{m}$ のミリポアフィルターでろ過したものをそれぞれ隇 菌蒸留水でプレートあたり 0.1 ～10 mg になるように希 釈して検液とした。

菌株は Salmonella typhimurium TA 98 及び TA 100 を用い Ames の原法”を一部改良したプレインキュ ベート法5゙により試験を行った.

代謝活性化にはフェノバルビタール (PB) あるいはポ リ塩化ビフェニル (PCB) を飲料水により投与し飼育し たラットの肝藏ホモジネートから得た S-9 画分を用い た。また，同時に S-9 画分を加えない場合についても試 験を行い, $37^{\circ}, 48$ 時間培養後の復帰変異コロニ一数を 算定し, 変異原性を観察した。

8) 鶏胚致死試験：試料をへキサン, ェーテル，アセ トンで順次抽出し，それぞれの抽出画分を濃縮乾固後, ジメチルスルホキサイドに溶解し，10 個を 1 群とした 有精卵 (5 日令) の畉黄囊 (Yolk sac) 内に接種し，4 日 間観察を行いその致死率を求めた.

\section{結果及び考察}

\section{1. 有害性元素及びその他の元素}

試料を原料あるいは成分により分類し，各元素の測定 結果を液状製品は Table 1 に, 粉末，顆粒及び錠剤様製 品は Table 2 に示した.

1) 液状製品

As は一般に海産物中に多く含有されているが，これ らを原料とする製品のうち，しじみェキスは $19 \mathrm{ppm}$ ， 海藻エキス濃縮液は $14 \mathrm{ppm}$ と高い值を示した。なお, 

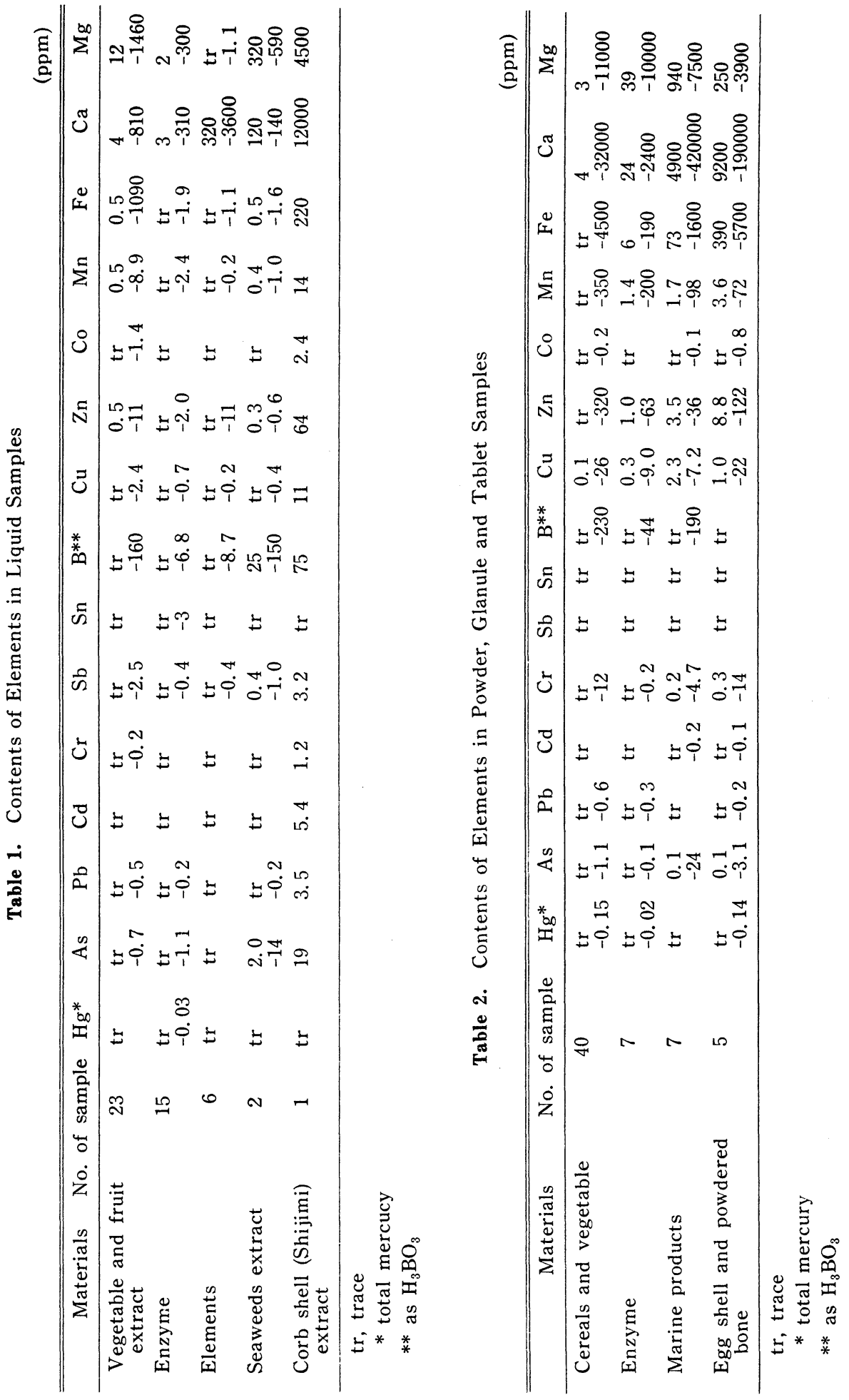
この海藻エキス濃縮液は清涼飲料水の表示があるにもか かわらず, 記載されている希釈倍率を考慮しても清涼飲 料水成分規格の As の基準值 $(0.2 \mathrm{ppm})$ を上回った.

$\mathrm{Pb}$ 及び $\mathrm{Cd}$ はしじみェキスでそれぞれ $3.5 \mathrm{ppm}$, $5.4 \mathrm{ppm}$ と他の製品あるいは一般の食品と比較すると 高く, その他の元素も比較的高い值を示した。 これは, この製品が非常に濃縮されたものであるためと思われ る.

Sb は高麗人参濃縮液が 2.5 ppm の值を示した.

$\mathrm{Fe}$ はホウレンソウを主原料とした製品から，1,090 ppm の值が得られた.

B はプルーンエキス 5 検体がいずれもホウ酸として 94〜160 ppm の值を示した.

2) 粉末，顆粒及び錠剤様製品

As はヒジキを原料とした製品から $24 \mathrm{ppm}$, ワカメ, コンブを原料とした製品からは，それぞれ $4.9 \mathrm{ppm}$, $4.8 \mathrm{ppm}$ と海産物を原料とした製品は液状製品の場合 と同様, いずれも高い值を示した.

$\mathrm{Hg}$ は高麗人参粉末に $0.15 \mathrm{ppm}$, 天然ミネラル製品 に $0.14 \mathrm{ppm}$ 含まれ, 他の製品に比較して高い值を示し た.

$\mathrm{Pb}$ 及び $\mathrm{Cd}$ は特に高い值は見られなかった.

$\mathrm{Cu}$ はコンフリー, 枸杞及び高麗人参などの粉末製品 に $20 \mathrm{ppm}$ 程度含まれていた.

$\mathrm{Zn}$ 及び Mn は小麦, 大麦などの胚芽製品に $100 \mathrm{ppm}$ を越える例が多く見られた。

$\mathrm{Cr}$ は天然ミネラル製品には $14 \mathrm{ppm}$, コンフリー粉末 には $12 \mathrm{ppm}$ 含まれていた。

$\mathrm{Fe}$ は $\mathrm{Cr}$ と同様, 天然ミネラル製品, コンフリー粉 末に，それぞれ $5,700 \mathrm{ppm}, 4,500 \mathrm{ppm}$ 含まれていた.

これらいわゆる健康食品に有害性元素が含有される原 因は，原料となる動物あるいは植物などの生育環境の影 響だけでなく製造工程中での混入，污染なども考えら れ，原因については十分調査する必要があると思われ る.

これらのいわゆる健康食品を摄取する場合は数倍から 数十倍に希釈して飲用するものもある. また，各元素は その存在形態により毒性の違いなども考えられるため, 今回検出された比較的高い数値が一概に問題とすべき量
であるか否かの判断は困難である. しかし，製品によっ ては摂取方法の不明確なものもあり, 消費者によっては 特定の製品を好んで摂取する可能性も高いので，有害性 元素については可能な限り, 含有量を減少させる必要が あると考える。

\section{2. 農 薬}

残留農薬は Table 3 に示すように有機塩素剂が夜状 製品で 1 検体, 粉末製品で 3 検体に検出された.

このうち, 高麗人参濃縮液及び同粉末は, 総 BHC が それぞれ $0.36 \mathrm{ppm}, 0.53 \mathrm{ppm}$ と一般農作物の残留基 準値の $0.2 \mathrm{ppm}$ と比較すると，それぞれ 1.8 倍, 2.6 倍の高い值を示した。

高麗人参粉末ではその他, ディルドリンが 0.03 ppm, ヘプタクロルエポキシドが $0.17 \mathrm{ppm}$ 検出された。 ま た，松葉エキス粉末では総 $\mathrm{BHC}$ が $0.07 \mathrm{ppm}$, 枸杞粉 末では総 $\mathrm{BHC}$ が $0.05 \mathrm{ppm}$ 検出された.

な敃，有機りン剂は液状，粉末，顆粒及び錠剂様のい ずれの製品からも検出されなかった。

\section{3. カ ビ 毒}

カビの代謝産物であり，強い発ガン性を有するアフラ トキシン $\mathrm{B}_{1}$ が穀類加工粉末製品 1 検体から検出され た. この製品は大麦, 小麦, コーンなぞの款類を主原料 とするもので, アフラトキシン $\mathrm{B}_{1}$ が $15 \mathrm{ppb}, \mathrm{B}_{2}$ が 2.5 $\mathrm{ppb}$ 検出された.

この原因としては，大麦及び小麦のアフラトキシンに よる自然污染例は非常に少ないので, 污染(例(8),7) が比較 的多いコーンによる污染と推察される.

このように，いわゆる健康食品として市販されている 製品から，強い毒性を有するアフラトキシンが検出され たことは問題であると思われる.

なお，この製品についてはその後, 同一会社の製品を 購入し調查を行ったがロットの異なることもあり，アフ ラトキシンは検出されなかった.

\section{4. ホルムアルデヒド}

人参エキス，リンゴ酢などを主原料とするカルシウム 含有飲料から $3.3 \mathrm{ppm}$ ，コンフリー粉末から $8.2 \mathrm{ppm}$ 検出された.

これらの数値はすでに報告8),9) の見られるシイタケ， タラなどの天然成分としての検出量に比較すると低い値

Table 3. Concentration of Pesticide Residues

(ppm)

\begin{tabular}{lcccccc}
\hline \multicolumn{1}{c}{ Sample } & $\alpha$-BHC & $\beta$-BHC & $\gamma$-BHC & Dieldrin & $\begin{array}{c}\text { Heptachlor } \\
\text { epoxide }\end{array}$ & $\begin{array}{c}\text { Organophosphrus } \\
\text { pesticide residues }\end{array}$ \\
\hline Korean ginseng extract & 0.20 & 0.14 & 0.02 & nd & nd & nd \\
Korean ginseng powder & 0.07 & 0.38 & 0.08 & 0.03 & 0.17 & nd \\
Pine needle extract powder & 0.05 & nd & 0.02 & nd & nd & nd \\
Boxthorn powder & 0.02 & nd & 0.03 & nd & nd & nd \\
\hline
\end{tabular}


であるが，その含有原因については十分調査する必要が あると思われる。

\section{5. 食品添加物}

保存料, 甘味料, 着色料, 漂白剤及び酸化防止剂につ いて調査を行った.

保存料は安息香酸がプルーンエキス 4 検体から 4 〜 13 $\mathrm{ppm}$ ，野菜，果実などを原料とする酵素飲料 2 検体から 共に $4 \mathrm{ppm}$ 検出され，粉末製品でも原料が肧芽のもの 8 検体, 松葉のもの 2 検体及び花粉のもの 2 検体から $0.7 \sim 30 \mathrm{ppm}$ 検出された. これらは含有量から考えて いずれも天然由来と思われる。

漂白剤はコンニャク芋（コンニャクマンナン）を原料 とする粉末製品から二酸化イオウが $80 \mathrm{ppm}$ 検出され た.これは，こんにゃく粉の製造工程中，乾燥のため使 用される重油中のイオウ化合物がこんにゃく粉中へ移行 したものと推察される.

酸化防止剂のうち L-アスコルビン酸がコンフリー, 熊 笹，南瓜を原料とする粉末あるいは顆粒製品 4 検体か ら，100 $\mathrm{g}$ につき $2.5 〜 108 \mathrm{mg}$ 検出された. また， $\alpha$-卜 コフェロールが肧芽, コンフリーを原料とする粉末製品 3 検体から 33 77 ppm, ビタミン $\mathrm{E}$ カプセル製品から $32,000 \mathrm{ppm}$ 検出された.

なお，その他の添加物はいずれの製品からも検出され なかった。

\section{6. 生物学的試験}

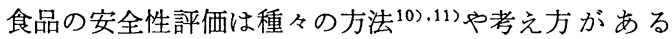
が，限られた試料から不特定多数の污染物質あるいは有 毒物質を調查することは困難である．とこで何らかの毒 性物質の有無を知る一つの手段として今回，生物学的方 法のらち, 変異原性試験及び鵎胚致死試験を用い毒性ス クリーニングを行った.

\section{1) 変異原性試験}

液状製品では高麗人参濃縮液が Fig. 1 に示すように, TA 98 でプレート当り $25 \mathrm{mg}$ の時に PCB 前処理した ラットからの S-9 の存在下で変異原性を示した.

この活性物質が高麗人参の成分によるものか, この試 料特有のものかを確認するため新たに， 5 種類の高麗人 参濃縮液を購入して同様の試験を行った。 その結果，そ れらからは活性が認められなかった．従って，この活性 物質は元来，人参中に含有される成分ではなく製造法な どの違い，あるいは農薬の残留が原因とも考兄られた。

そこで，すでに変異原性の確認されている4) ベンツピ レンが，濃縮工程中で生成される可能性も考え調査した がベンツピレンは検出されなかった。 また，農薬による 影響については，この高麗人参濃縮液より検出された BHC は一般に変異原性が見られないと言われている ${ }^{12)}$. この变異原性を有する物質については継続して調査を行 っている.

粉末製品では花粉製品 2 検体でプレート当り $10 \mathrm{mg}$

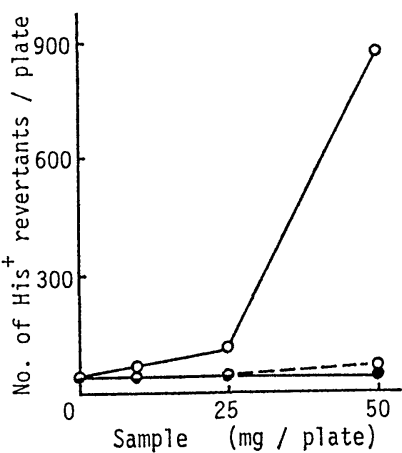

Fig. 1. The mutagenic response of $S$. typhimurium strains TA 98 to various amount of Korean ginseng extract

$-\bullet-,-\mathrm{S}-9$; - $\mathrm{O}-$, +S-9 (PCB); --O--, $+\mathrm{S}-9$ (PB)
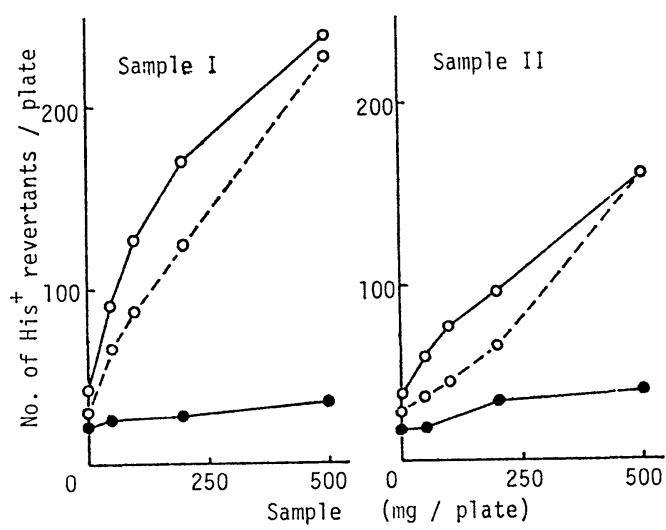

Fig. 2. The mutagenic response of $S$. typhi. murium strains TA 98 to various amount of acetone extract of two pollen granules (I and II)

$-\bullet-,-\mathrm{S}-9$; - $-\mathrm{O},+\mathrm{S}-9$ (PCB); --O--, +S-9 (PB);

のとき，TA 98 及び TA 100 でわずかに変異原性が見 られた。

そこで, 試料をへキサン, エーテル，アセトンで順次 抽出を行い，各画分について試験を行ったところ，2検 体ともアセトン抽出画分が Fig. 2 に示すように, TA 98 でプレート当り元の試料に換算して $50 \mathrm{mg}$ から S-9 の存在下で活性を示した。 な扐，TA 100 でもやや弱い 活性を示した.この 2 検体はいずれも花粉製品であった ことから，活性はその成分によるものと推察された.

そこで，花粉の共通成分であるフラボノイド類のら ち，特に変異原性の確認されているケルセチン ${ }^{13) .14)}$ 着目し同定を試みた。

活性を示したアセトン抽出画分について，薄層クロマ 
トグラフィー及び蛍光デンシトメトリーを行った結果,

Fig. 3 に示す薄層クロマトグラム及び Fig. 4 に示す蛍 光スペクトルが得られ，これらはいずれもケルセチンの 挙動と一致した.

そこで本物質をケルセチンと仮定して花粉製品 2 検体 (試料 I 及び II) について，ケルセチン含有量を蛍光デ ンシトメトリーにより測定したところ, 試料 I では 11.8 $\mu \mathrm{g} / \mathrm{g}$, 試料 II では $7.6 \mu \mathrm{g} / \mathrm{g}$ が検出された.

これらのケルセチンが变異原性を示す活性本体である かどらかを，ケルセチン標準物質の mutagenic activity と比較検討した.

Fig. 2 のらち, 試料 $500 \mathrm{mg}$ の場合, そのケルセチン 含有量は $5.9 \mu \mathrm{g}$ 及び $3.8 \mu \mathrm{g}$ となる. このとさの変異 コロニー数を，Fig. 5 に示したケルセチン標準物質の dose response curve に扎いて, 試料中のケルセチンと 同濃度の標準物質の変異コロニー数と比較すると,いず

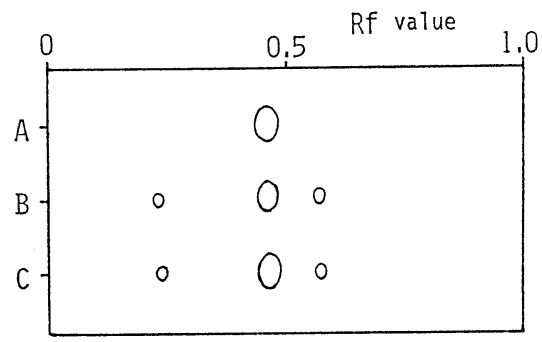

Fig. 3. Thin layer chromatogram of acetone extract of pollen granule

A, quercetin; B, C, acetone extract of pollen granule

Developing solvent, toluene-formic acid -ethyl formate $(5: 1: 4)$; Detection, UV light (365 nm) Treatment, spray with $4 \% \mathrm{Al}_{2}\left(\mathrm{SO}_{4}\right)_{3}$

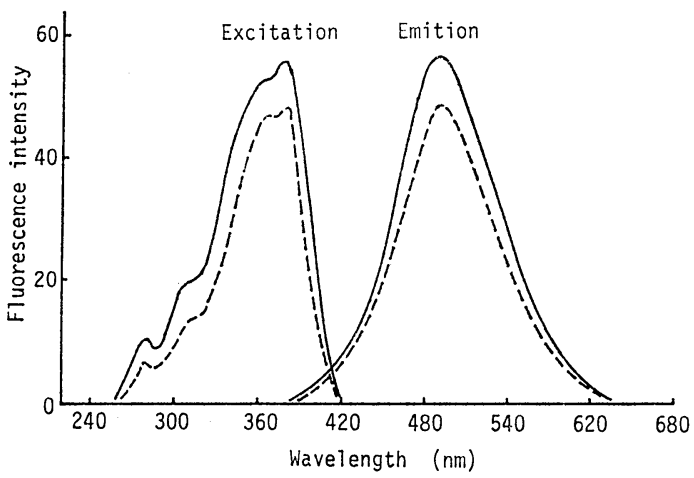

Fig. 4. Fluorescence and excitation spectra of acetone extract of pollen granule - , quercetin; ----, acetone extract of pollen granule

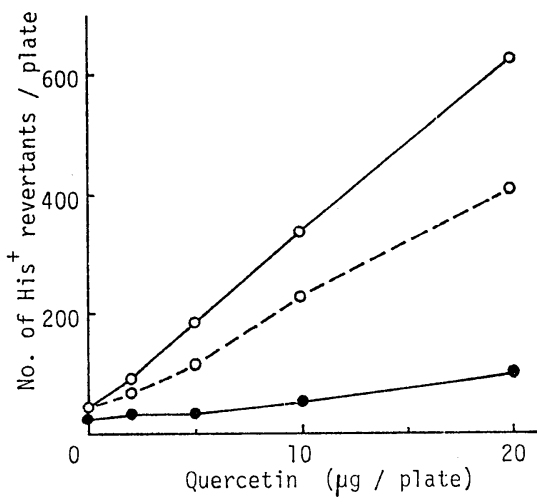

Fig. 5. The mutagenic response of $S$. typhimurium strains TA 98 to various amount of quercetin

$-\bullet-,-\mathrm{S}-9$; -O-, +S-9 (PCB); --O--, $+\mathrm{S}-9$ (PB)

れも同程度のコロニー数であった.

以上のことは，アセトン抽出画分の活性物質が，ヶル セチンであることを強く示唆する.

従って，花粉製品の変異原性を示す物質は，ケルセチ ンであることが推察される。

2) 鵎胚致死試験

液状製品では特に活性を示すものはなかったが, 粉末, 顆粒及び錠剂様製品では Table 4 に示すように，原料 が穀類, 野菜などのもの 6 検体, 酵素のもの 1 検体, 水 産物（シジミ）のもの 1 検体の計 8 検体で活性が見られ た. このらち, 穀類, 野菜などを原料とするものでは 5 検体が胚芽製品であった.

これら 8 検体はいずれもへキサン抽出画分で活性が見 られたことから，この活性物質は各試料に共通したへキ サン可溶物質である油脂が考えられた.

油脂が変敗した場合，生成される過酸化物などが䳕胚 に対し強い作用を及ぼすことは知られている ${ }^{15)}$ が，各試 料ともに㧤いは良好であり, かつ, 過酸化物価も低い值 であった。

また，川に生育する水草を原料とする製品は，すべて の画分で活性が見られたことから，各抽出画分を濃縮乾 固後, オリーブオイルに混和し， 1 群10匹の 5 週令マウ ス (ddY 系雌, 平均体重 $19 \mathrm{~g}$ ) に試料 $5 \mathrm{~g}$ 相当量を腹腔 内に注入したが， 2 週間の観察では特に変化は見られて いない.

これらの活性物質については継続して検討を行ってい る。

\section{ま とめ}

市販のいわゆる健康食品のうち, 液状製品 47 検体, 粉 末, 顆粒及び錠剤椂製品59検体について各種元素, 農薬, カビ毒, ホルムアルデヒド及び食品添加物などの調査の 
Table 4. Effect of Various Samples Inoculated into the Air Cells on Chicken Embryos

\begin{tabular}{|c|c|c|c|}
\hline \multirow{2}{*}{ Principal materials } & \multicolumn{3}{|c|}{ Toxity* } \\
\hline & Hexane extract & Ethyl ether extract & Acetone extract \\
\hline Embryo bud & $9 / 10(1)^{* *}$ & & \\
\hline Embryo bud & $6 / 10 \quad(0.5)$ & $9 / 10 \quad(1)$ & \\
\hline Embryo bud & $6 / 10 \quad(0.5)$ & $4 / 10$ & \\
\hline Embryo bud & $8 / 10(1)$ & & \\
\hline Garlic & $8 / 10(1)$ & & \\
\hline Aquatic plant & $9 / 10 \quad(1)$ & $9 / 10 \quad(1)$ & $10 / 10 \quad(1)$ \\
\hline Enzyme & $9 / 10 \quad(1)$ & & \\
\hline Tangle (Konbu) & $5 / 10(1)$ & & \\
\hline
\end{tabular}

* No. of dead / No. of treated

** Volume of sample, g/egg

Sample was mixed with dimethyl sulfoxide

他に, 変異原性試験及び鷄胚致死試験の生物学的試験を

行い衛生学的検討を行った.

その結果, $\mathrm{Hg}, \mathrm{As}$ などが高麗人参粉末, しじみェキ スあるいはヒジキを原料とする錠剤様製品などから通常 の食品と比較して高濃度に検出された.

農薬のうち $\mathrm{BHC}$ ，デイルドリン及びへプタクロルェ ポキシドが高麗人参濃縮液及び同粉末から検出された.

強力な発ガン物質であるアフラトキシン $\mathrm{B}_{1}$ がコーン などを原料とする穀類加工粉末製品 1 検体から検出され た。

変異原性試験では 3 検体, 鷄胚致死試験では 8 検体で 陽性を示した。

本調査では各種類とも試料数が少なく, 調査項目が限 られているので, すべてのいわゆる健康食品に対する安 全性の評価は困難であるが，種々の有害物質が検出され ており, 今後も継続して一般食品と同様に安全性のチェ ックを行う必要があると考える.

なお，本研究の概要は日本食品衛生学会第38回学術講 演会（1979年10月，仙台）及び同第40回（1980年11月， 長野) において発表した。

\section{文献}

1) 昫句生嘉明, 大貫憲一, 山岸 䆖, 白鳥憲行: 食品 衛生呼究 28,747〜752 (1978).

2) 田村行弘, 真木俊夫, 嶋村保洋, 西垣 進, 直井 家壽太：食衛誌. 20, 173～180 (1979).
3) 厚生省通知，環食 128 号（昭和 46 年 3 月 16 日).

4) Ames, B. N., McCann, J., Yamasaki, E.: Mutat. Res. 31, 347 364 (1975).

5) 矢作多貴江：蛋白翼 - 核酸・酵素 $20,1178 \sim 1189$ (1975).

6)農林水産省食品総合研究所編：食糧 19，62７4 (1977).

7) 鶴田 理, 杉本貞三, 南沢正敏, 真鍋 勝：日菌 報. 15, 258〜265 (1974).

8) 矢田光子, 今井田雅示, 小林太郎：食衛誌. 11, $171 \sim 176$ (1970).

9) 岡田敏央, 伊賀宗一郎, 伊阪 博：衛生化学 18, 353 357 (1972).

10) 内山 充：食衛誌。 24, 249 257 (1983).

11）河端俊治：食品衛生研究 29, 929 940 (1979).

12) Shirasu, Y., Moriya, M., Kato, K., Furuhashi, A., Kada, T.: Mutat. Res. 40, 19 30 (1976).

13) Bjeldanes, L. F., Chang, G. W.: Science 197, 577 578 (1977).

14) Seino, Y., Nagao, M., Yahagi, T., Sugimura, T., Yasuda, T., Nishimura, S.: Mutat. Res. 58, 225〜229 (1978).

15) 三浦利之, 土田雅子, 宮木高明：油化学 20,13～ 18 (1971). 